\title{
Consumption of labile dissolved organic matter by limnetic bacterioplankton: the relative significance of amino acids and carbohydrates
}

\author{
Martina Weiss, Meinhard Simon* \\ Limnological Institute, University of Constance, D-78457 Konstanz, Germany
}

\begin{abstract}
We studied the seasonal dynamics and consumption by planktonic bacteria of the labile pools of dissolved organic carbon (DOC $\mathrm{Cab}_{\mathrm{lab}}$ ), dissolved amino acids (TDAA $\mathrm{A}_{\text {la b }}$ ), and dissolved carbohydrates $\left(\mathrm{TDCHO}_{\mathrm{lab}}\right.$ ) in Lake Constance, Germany, between March and October 1994. The labile pools were defined as those fractions consumed by bacteria in $1 \mu \mathrm{m}$ filtered samples over $4 \mathrm{~d}$. DOC lab varied from 0.064 to $0.606 \mathrm{mg} \mathrm{C}^{-1}$ and constituted 5 to $36 \%$ of bulk DOC, which ranged between 1.45 and $2.3 \mathrm{mg} \mathrm{Cl} \mathrm{Cl}^{-1}$. Proportion of $\mathrm{DOC}_{\mathrm{lab}}>13 \%$ occurred during the phytoplankton spring bloom, whereas later in the year $<13 \%$ of bulk DOC was labile. The bacterial growth efficiency, i.e. the ratio of biomass produced over DOC consumed, ranged from 8 to $57 \%$ with a mean of $23 \%$ and no obvious seasonal trend. TDAA $A_{\text {lab }}$ constituted 10 to $73 \%$ of bulk TDAA and 5 to $95 \%$ of $\mathrm{DOC}_{\text {lab }}$, respectively, with highest proportions during the spring bloom, the clear-water phase (not of $\mathrm{DOC}_{\text {lab }}$ ), and a phytoplankton bloom in July. TDCHO lab constituted 24 to $73 \%$ of bulk TDCHO and 5 to $86 \%$ of DOC lab respectively, with highest proportions during the clear-water phase and in September. TDAA $A_{\text {lab }}$ and TDCHO lab were positively correlated to bulk TDAA and bulk TDCHO, respectively. Even though both substrate classes were the major components of the labile DOC and together constituted 47 to $100 \%$ of $\mathrm{DOC}_{\mathrm{lab}}$ in $75 \%$ of the experiments, they were not utilized to equal amounts but relative proportions varied considerably from May to September. Both substrates often were also utilized differently for biosynthetic and energy requirements as demonstrated by respiration measurements of ${ }^{14} \mathrm{C}$-amino acids and ${ }^{14} \mathrm{C}$-glucose. During the spring bloom amino acids were respired preferentially, whereas during the summer bloom glucose was respired preferentially. Turnover times of amino acids and glucose also demonstrated that both substrate classes were utilized differently because turnover times of glucose were consistently longer than those of amino acids except in surface waters from mid-July until September.
\end{abstract}

KEY WORDS: DOM - Bacteria - Bacterial production - Amino acids - Carbohydrates - Growth efficiency Respiration - Lake Constance

\section{INTRODUCTION}

The large pool of dissolved organic matter (DOM) in aquatic ecosystems is composed of a labile fraction which is turned over rapidly, i.e. within days, and a recalcitrant fraction with a slow turnover time of weeks, years, decades and even longer time scales

\footnotetext{
-Addressee for correspondence. Present address: Institute for Chemistry and Biology of the Marine Environment, University of Oldenburg, PO Box 2503, D-26111 Oldenburg, Germany. E-mail: m.simon@icbm.uni-oldenburg.de
}

(Hedges 1992, Münster 1993, Søndergaard \& Middelboe 1995). Even though various sources contribute to the inputs of DOM to aquatic ecosystems, such as phytoplankton primary production (Baines \& Pace 1991), sloppy feeding and egestion by zooplankton (Lampert 1978, Strom et al. 1997), and allochthonous DOM (Tranvik 1988, Volk et al. 1997), consumption by heterotrophic planktonic bacteria is the most significant sink for the DOM pool. Depending on the trophic state and the seasonal situation of the system and its allochthonous inputs the labile fraction can comprise from $<5$ to $\mathrm{ca} 30 \%$ of the total DOM in marine, riverine, and lacustrine environments (Tran- 
vik 1988, 1990, Kirchman et al. 1991, Middelboe \& Sondergaard 1993, Søndergaard \& Middelboe 1995, Søndergaard et al. 1995, Amon \& Benner 1996, Volk et al. 1997). There is still little information available, however, on the seasonal variability of the amount of labile DOM in absolute terms and relative to the total DOM.

The most important components of the labile DOM are dissolved free (DFAA) and combined amino acids (DCAA) and dissolved free (DFCHO) and combined carbohydrates (DCCHO). Many studies were conducted during the last decade which examined the bacterial consumption and turnover of DFAA and DCAA over space and time (e.g. Jørgensen 1987, Coffin 1989, Simon \& Rosenstock 1992, Jørgensen et al. 1993, Keil \& Kirchman 1993, Rosenstock \& Simon 1993, Middelboe et al. 1995). Very few studies have examined the bacterial turnover and consumption of DFCHO (Jørgensen 1990, Jøigensen \& Jensen 1994, Rich et al. 1996) and DCCHO (Jørgensen \& Jensen 1994, Tranvik \& Jørgensen 1995, Hanisch et al. 1996, Jørgensen et al. 1998), and there is still very little information on the seasonal dynamics of the bacterial consumption of total dissolved carbohydrates (TDCHO). Even less information exists about the relative significance of total dissolved amino acids (TDAA) and TDCHO as bacterial substrates on the basis of simultaneous measurements. Only in a few experiments has the bacterial consumption of TDAA and TDCHO been measured simultaneously (Schweitzer \& Simon 1995. Tranvik \& Jørgensen 1995, Hanisch et al. 1996, Volk et al. 1997, Jørgensen et al. 1998). In order to better understand the relative significance of amino acids and carbohydrates as substrates for bacterial growth more studies covering various trophic and seasonal situations have to be carried out which examine the labile fractions of TDAA and TDCHO and their simultaneous consumption.

When substrates are consumed, they are partly used for biosynthesis and partly for energy requirements, i.e. respired. Quite a few studies measured the respiration of either amino acids (e.g. Jørgensen 1987, Simon \& Tilzer 1987, Coffin 1989, Suttle et al. 1991) or monosaccharides (Berman \& Gerber 1980, Riemann et al. 1982, Jørgensen \& Jensen 1994), showing that the relative respiration as percent of gross uptake can vary greatly. However, so far there is only very scarce information on the relative respiration of both amino acids and monosaccharides based on simultaneous measuments (Berman \& Gerber 1980, Suttle et al. 1991. Tranvik \& Jørgensen 1995). Such measurements are important to understand the control of the relative utilization and preferences of these labile DOM components for biosynthetic and energy requirements of planktonic bacteria.
We measured the consumption of TDAA and TDCHO by planktonic bacteria from March to October 1994 in mesotrophic Lake Constance, Germany, together with bacterial growth dynamics and determined the labile and recalcitrant fractions of both classes of organic compounds. We also studied the turnover and respiration of amino acids and monosaccharides to examine when and under which conditions amino acids or carbohydrates are preferred for biosynthetic or energy requirements.

\section{MATERIALS AND METHODS}

The study was carried out between March and October 1994 at the center and deepest point of Lake Überlingen, the northwestern fjord-like arm of prealpine Lake Constance, adjacent to Austria, Germany and Switzerland. Lake Constance is a mesotrophic and warm-monomictic lake with a surface area of $539 \mathrm{~km}^{2}$ and maximum and mean depths of 254 and $100 \mathrm{~m}$, respectively. Lake Überlingen has maximum and mean depths of 147 and $90 \mathrm{~m}$, respectively. Lake Constance underwent oligotrophication during the last 15 yr due to an effective reduction of the P-load (Güde et al. 1998). Plankton dynamics have been studied extensively during the recent past (e.g. Gaedke \& Straile 1994, Weisse \& Müller 1998, Simon et al. 1998). Samples were collected with a clean van Dorn bottle at 2,8 and $20 \mathrm{~m}$ and immediately transferred into clean 1 and 21 polyethylene bottles and kept in a cooling box until further processing in the lab, which was not later than $2 \mathrm{~h}$ after sampling. From mid-July until the end of the study samples were collected at 40 instead of $20 \mathrm{~m}$ to make sure that the true hypolimnion was sampled and not the metalimnion because pronounced internal seiches occur in Lake Überlingen in summer when the lake is stratified.

To study the consumption of DOC, TDAA and TDCHO by planktonic bacteria $1 \mu \mathrm{m}$ prefiltered samples were incubated for 90 to $100 \mathrm{~h}$ at in situ temperature in the dark and subsampled periodically for measurements of bacterial numbers and cell volumes and concentrations of DOC, TDAA and TDCHO. Therefore, samples from $2 \mathrm{~m}$ were prefiltered through $1 \mathrm{\mu m}$ Nuclepore filters by gravity to minimize substrate enrichment due to leaking and damage of algae and other protists. After every $100 \mathrm{ml}$ the filter was replaced by a new one to avoid clogging. The experiments were run in duplicates of $500 \mathrm{ml}$. A total of 12 experiments were carried out but only 10 experiments measured the consumption of TDAA, and 4 experiments measured the consumption of TDCHO. Usually the duplicates exhibited the same patterns of bacterial growth and DOC consumption over time and they 
agreed within $20 \%$. Because with duplicates no standard deviation can be determined the data are presented as mean values and the range of the duplicates (Table 1, see Figs. 2 \& 4).

The labile fractions of DOC (DOClab), TDAA (TDAA lab $_{\text {) and TDCHO (TDCHO }}$ lab) were defined according to Middelboe \& Sondergaard (1993) as the amount consumed in the $1 \mu \mathrm{m}$ filtrates until the bacterial growth reached the stationary phase. The residual concentrations were considered as the recalcitrant fractions

Samples for bacterial numbers, fixed with $2 \%$ Formalin, were counted on black $0.2 \mu \mathrm{m}$ Nuclepore filters by epifluorescence microscopy with a Nikon microscope (Labophot 2A) after staining with DAPI $\left(4^{\prime}, 6-\right.$ diamidino-2-phenylindole) according to Porter \& Feig (1980). Bacterial cell sizes were determined with a semi-automatic image analysis system (AI-Tectron, Düsseldorf, Germany) on magnified photomicrographs, taken with a Nikon FX-350X camera on a KODAK 400 Tmax film. From the measured length (l) and width $(w)$ the cell volume $(V)$ was calculated as $V$ $=1 / 4 \times \pi \times w^{2} \times 1 / 3 \times(l-w)$. Comparisons with acridine orange-stained samples showed that the cell volume was underestimated by $7 \%$ in DAPI-stained samples. Thus, the cell volume was multiplied by 1.075 . Cell carbon was calculated from the cell volume according to Simon \& Azam (1989).

Bacterial production was measured by the incorporation of ${ }^{14} \mathrm{C}$-leucine (Leu) according to Kirchman et al. (1985) and Simon \& Azam (1989). Four subsamples of $5 \mathrm{ml}$ were transferred into clean polystyrene test tubes and labelled with ${ }^{14} \mathrm{C}$-leucine $\left(310 \mathrm{mCi} \mathrm{mmol}^{-1}\right.$, Amersham) at a final concentration of $30 \mathrm{nM}$, which maximizes incorporation rates in Lake Constance (Simon \& Rosenstock 1992). One sample served as a blank and was immediately fixed with Formalin (2\% final concentration) and the others were incubated for $1 \mathrm{~h}$ in the dark at in situ temperature and fixed thereafter. The samples were then filtered onto $0.45 \mu \mathrm{m}$ nitrocellulose filters (Sartorius), extracted with ice-cold $5 \%$ trichloroacetic acid (TCA) for $5 \mathrm{~min}$, rinsed with $5 \%$ TCA and twice with $80 \%$ ethanol and radioassayed by liquid scintillation counting. The coefficient of variation $(\mathrm{CV}$, standard error/mean) of the triplicate measurements usually was $<0.10$. Bacterial production was calculated according to Simon \& Azam (1989) assuming a 2-fold isotope dilution of Leu and a partitioning of Leu in the protein fraction of $86 \%$ of the total macromolecular fraction (Simon \& Rosenstock 1992).

To determine turnover rates of dissolved free amino acids four $50 \mathrm{ml}$ subsamples were transferred into clean $100 \mathrm{ml}$ Erlenmeyer flasks with screw caps and labelled with a mixture of ${ }^{14} \mathrm{C}$-amino acids $(53.2 \mathrm{mCi}$ [milliatom $\mathrm{Cl}^{-1}$, Amersham) at $5 \mathrm{nM}$ final concentra- tion. One flask was immediately fixed with Formalin ( $2 \%$ final concentration) and served as a blank and the others were incubated at in situ temperature in the dark for $1 \mathrm{~h}$ and fixed thereafter. Ten ml from each flask was withdrawn and filtered onto a $0.45 \mu \mathrm{m}$ nitrocellulose filter, rinsed with particle-free lake water and radioassayed. In the remaining $40 \mathrm{ml}$ respiration was measured according to Hobbie \& Crawford (1969). After acidification of the sample in the closed flask by a syringe through a silicon septum with phosphoric acid the evolved ${ }^{14} \mathrm{CO}_{2}$ was trapped in accordeonfolded and phenethylamine-soaked filter paper (Whatman no. 1) fixed in a wire hook inside the neck of the flask. The acidified samples were shaken overnight such that $>98 \%$ of the ${ }^{14} \mathrm{CO}_{2}$ produced was trapped in the filter paper. The filter paper was radioassayed by liquid scintillation counting. The turnover rate was calculated as $\left(d p m_{\text {net }}+d p m_{\text {resp }}\right) / d p m_{\text {add }}$, where $d p m_{\text {net }}$ and $\operatorname{dpm}_{\text {resp }}$ are the amounts of tracer taken up and respired per hour and dpmadd is the amount of label added. The turnover time was calculated as the inverse of the turnover rate. Respiration is given as percent of gross uptake (net uptake + respiration).

Turnover and respiration rates of ${ }^{14} \mathrm{C}$-glucose (304 $\mathrm{mCi} \mathrm{mmol}^{-1}$, Amersham) were determined in the same way as those of amino acids and at the same added final concentration of $5 \mathrm{nM}$. The CV of the triplicate measurements of uptake and respiration of amino acids and glucose was always $<0.20$ and in $80 \%$ of the experiments $<0.10$.

DOC was analyzed in triplicates with a Dohrmann DC-180 TOC analyzer which works on the basis of wet oxidation. The samples, and also those for the analyses of TDAA and TDCHO (see below), were prefiltered

Table 1. Growth efficiencies of bacterioplankton in Lake Constance measured as the ratio of increase in bacterial biomass over decrease in DOC and over time in $1 \mu \mathrm{m}$ filtered samples from $2 \mathrm{~m}$ depth. Mean values and range of duplicates are given

\begin{tabular}{|lcc|}
\hline Date & \multicolumn{2}{c|}{ Growth efficiency } \\
& Mean & Range \\
\hline 26 April & 0.13 & $0.08-0.17$ \\
3 May & 0.26 & $0.22-0.31$ \\
17 May & 0.26 & $0.19-0.32$ \\
31 May & 0.08 & $0.06-0.10$ \\
14 June & 0.15 & $0.14-0.15$ \\
21 June & 0.39 & $0.28-0.51$ \\
5 July & 0.24 & $0.24-0.25$ \\
2 July & 0.27 & $0.21-0.33$ \\
16 August & $0.57^{\circ}$ & $0.06-0.10$ \\
13 September & 0.08 & $0.18-0.24$ \\
25 October & 0.21 & $0.10-0.22$ \\
ada of only 1 experiment available & \\
\hline
\end{tabular}




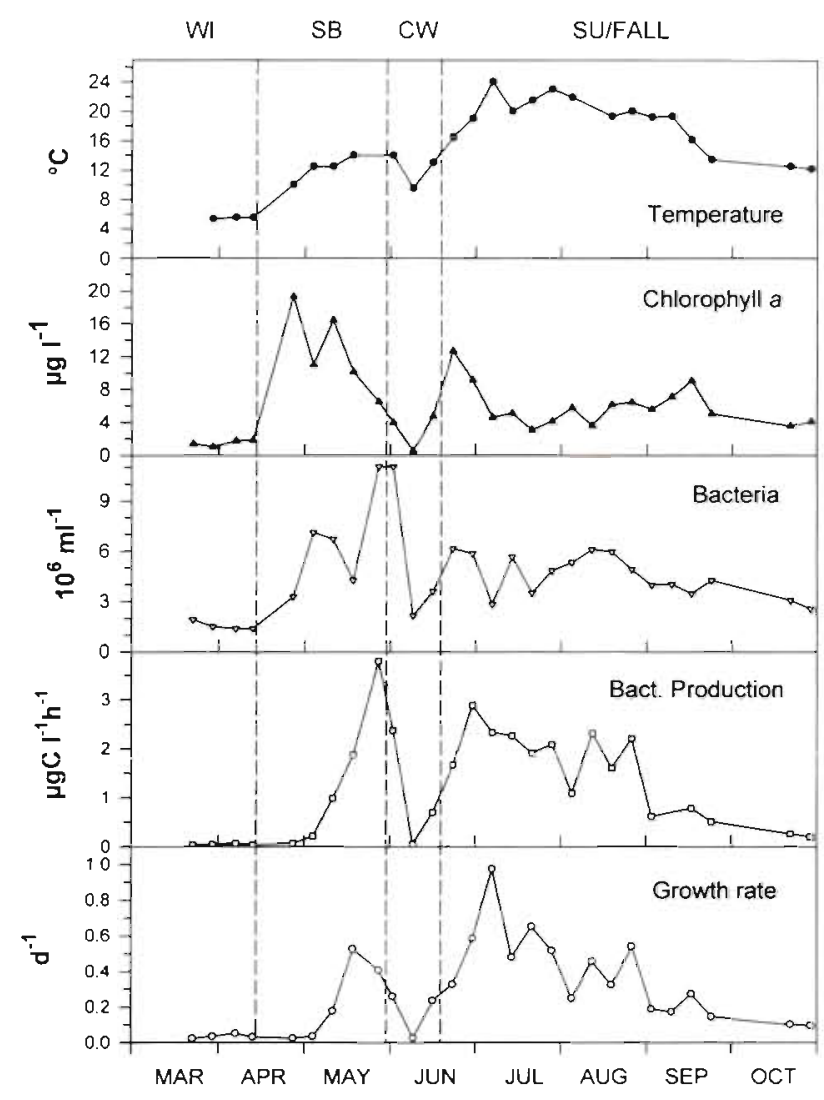

Fig. 1. Temperature, chlorophyll $a_{1}$ numbers, production and growth rates of planktonic bacteria in Lake Constance between March and October 1994 at $2 \mathrm{~m}$ depth. Wl: winter, SB: spring bloom, CW: clear-water phase, SU/FALL: summer and fall

through a $0.2 \mu \mathrm{m}$ Nuclepore filter under low vacuum $(<0.1 \mathrm{bar})$ and stored frozen until analysis within $2 \mathrm{mo}$. The filters were copiously rinsed with Milli- $Q$ water prior to filtering the samples. After thawing, samples were acidified prior to the analysis. TDAA were analyzed as DFAA after hydrolysis with $6 \mathrm{~N} \mathrm{HCl}$ at $110^{\circ} \mathrm{C}$ for $20 \mathrm{~h}$ by high performance liquid chromatography (HPLC) after ortho-phthaldialdehyde derivatization according to Lindroth \& Mopper (1979) as modified by Simon \& Rosenstock (1992). After prefiltration samples were stored frozen until analysis within $4 \mathrm{mo}$. TDCHO were analyzed by HPLC and pulsed amperometric detection after hydrolysis with $0.1 \mathrm{~N} \mathrm{HCl}$ at $100^{\circ} \mathrm{C}$ for $20 \mathrm{~h}$ with a DIONEX instrument and a Carbopac PA 1 column according to Mopper et al. (1992) using $22 \mathrm{mM}$ $\mathrm{NaOH}$ as eluent. After prefiltration samples were stored frozen until analysis after $2 \mathrm{yr}$. Concentrations of both TDAA and TDCHO are given either as equivalents of amino acid and monosaccharides in $\mu \mathrm{M}$ or in mg $\mathrm{C}^{-1}$. Chlorophyll a was analyzed spectrophotometrically after hot ethanol extraction according to Simon \& Tilzer (1987)

\section{RESULTS}

The study started prior to the onset of the phytoplankton spring bloom in late March. During April and May the lake warmed up and became thermally more and more stratified as indicated by the temperature gradually increasing to $14^{\circ} \mathrm{C}$. The highest temperature was reached in early July and slowly decreased thereafter to $13^{\circ} \mathrm{C}$ towards the end of October. The seasonal dynamics of the phytoplankton were characterized by the spring bloom with its maximum from late April to early May, the clear-water phase in June with chlorophyll a concentrations below $5 \mathrm{\mu g} \mathrm{l}^{-1}$, and by a summer bloom with highest chlorophyll concentrations at $2 \mathrm{~m}$ in late June (Fig. 1) and at 3 to $6 \mathrm{~m}$ in July (not shown). Bacterioplankton growth during the phytoplankton spring bloom peaked towards its decline in late May, when the annual maxima of bacterial numbers and production of $11 \times 10^{6} \mathrm{celis} \mathrm{ml}^{-i}$ and $3.7 \mu \mathrm{g} \mathrm{Cl}^{-1} \mathrm{~h}^{-1}$, respectively, were reached (Fig. 1). Thereafter, bacterial production dropped sharply in the clear-water phase but increased again towards the end of June and remained at 2 to $3 \mu \mathrm{g} \mathrm{C} \mathrm{l}^{-1} \mathrm{~h}^{-1}$ until the end of August. Bacterial growth rates roughly followed the pattern of bacterial production but exhibited highest rates of $1.0 \mathrm{~d}^{-1}$ in early July. At 20 and $40 \mathrm{~m}$ depth, bacterial numbers, rates of production and growth were always reduced as compared to 2 and $8 \mathrm{~m}$ (see Table 3 ). The mean bacterial cell volume varied between 0.036 and $0.065 \mu^{3}$, with highest values during the clear-water phase and lowest values in fall. The seasonal mean was $0.050 \mu \mathrm{m}^{3}$.

DOC concentrations were highest at the maximum of the spring bloom, reaching $2.3 \mathrm{mg} \mathrm{C}^{-1}$ (Fig. 2). A second peak occurred in late July at the end of the

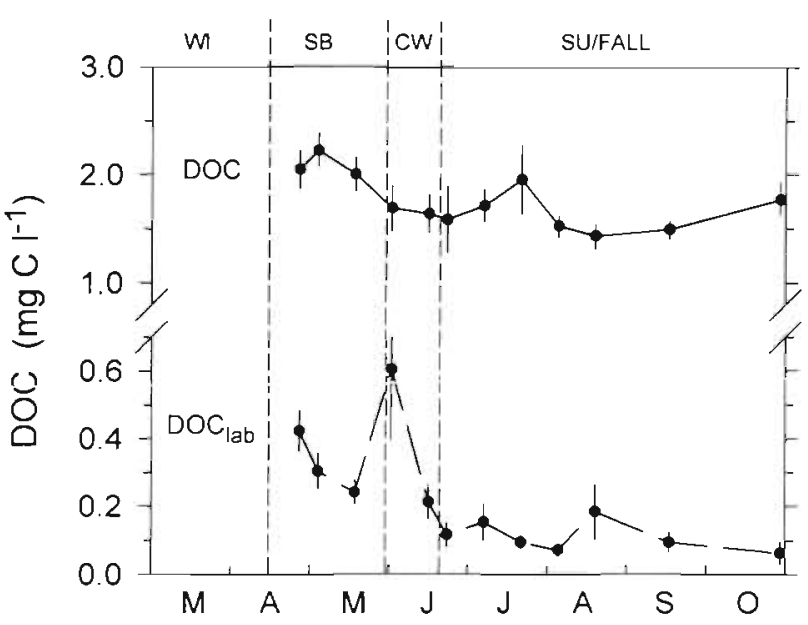

Fig. 2. Concentrations of bulk and labile DOC at $2 \mathrm{~m}$ depth in Lake Constance between late April and October 1994. For abbreviations see Fig. 1 For labile DOC mean values and range of duplicates are given 
summer phytoplankton bloom. In general, DOC concentrations did not exhibit large seasonal changes, ranging only from 1.45

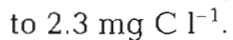

\section{Bacterial consumption of labile DOM and growth efficiency}

The concentration of labile DOC as determined by bacterial DOC consumption in $1 \mu \mathrm{m}$ filtered samples over time varied between 0.064 and $0.606 \mathrm{mg} \mathrm{C} \mathrm{l}^{-1}$ (Fig. 2) and comprised 5 to $36 \%$ of total DOC. Proportions exceeding $13 \%$ were measured during the spring bloom, whereas only $<13 \%$ of total DOC was labile during the remaining period.

During the incubations of the $1 \mu \mathrm{m}$ filtered samples bacteria grew in numbers and size and consumed measurable amounts of DOC (Fig. 3). The increase in bacterial biomass was predominantly due to cell multiplication, and the cell volume always increased less than 2 -fold. There was not always a continuous decrease in DOC concentrations over time, though, presumably because bacteria shifted from utilizing TDCHO to TDAA and vice versa, and also sometimes due to excretion of TDCHO (see below). The growth efficiency, i.e. the ratio of bacterial biomass produced divided by the amount of DOC consumed, varied from 8 to $57 \%$ but 11 out of 12 experiments yielded values $<40 \%$ (Table 1 ). The overall mean growth efficiency was $23 \%$. There was no systematic covariation of the growth efficiency with any other bacterial parameter seasonally.

TDAA and TDCHO always comprised a substantial proportion of the labile DOM. Labile TDAA comprised 10 to $73 \%$ of bulk TDAA with highest proportions during the spring bloom, the clear-water phase and in late July (Fig. 4). Concentrations of labile TDAA and bulk TDAA were significantly and closely correlated (Fig. 5, $p<0.01$ ). Labile TDAA constituted a variable fraction of the labile DOC, comprising 5 to $95 \%$ of it with most values ranging between 12 and $32 \%$ (Fig. 4). Highest values occurred during the spring bloom and in late July. There was, however, no significant correlation between concentrations of labile TDAA and labile DOC $(p>0.05)$.

In 4 experiments we also measured the bacterial consumption of labile TDCHO which constituted between 24 and $73 \%$ of bulk TDCHO and between 5 and $86 \%$ of DOClab (Table 2). Labile TDCHO and TDAA together constituted 48 to $108 \%$ of $D_{\text {lab }}$ (Table 2). The experiments showed that TDAA and

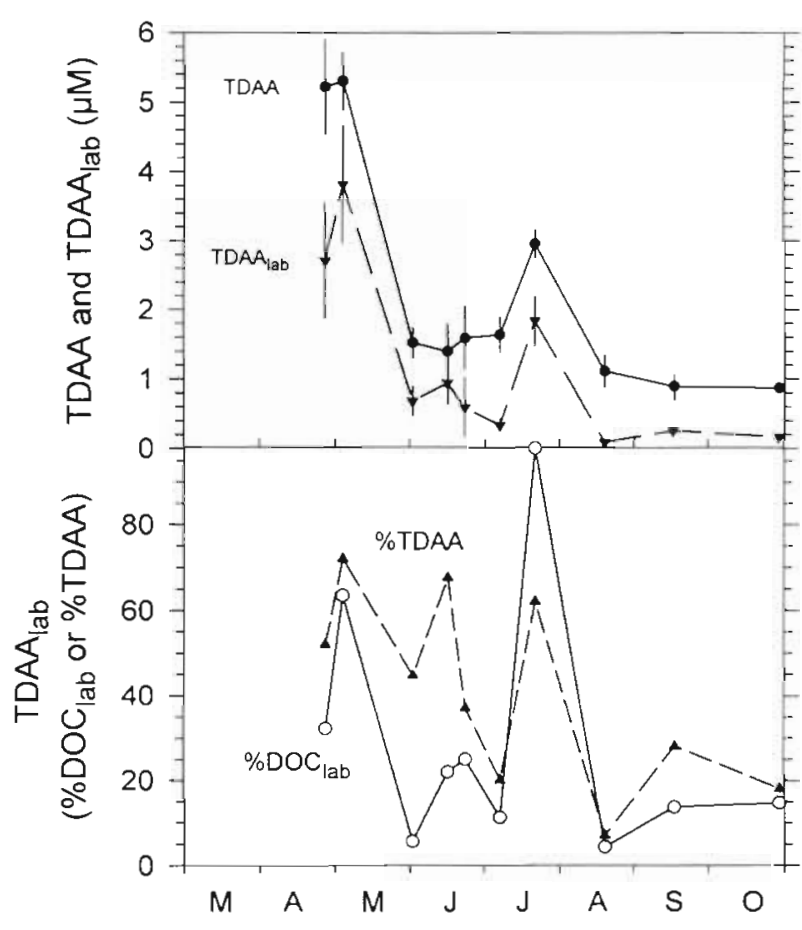

Fig. 4. Bulk and labile dissolved amino acids (TDAA, TDAA $_{\text {lab }}$ ) at $2 \mathrm{~m}$ depth in Lake Constance between late April and October 1994. Upper panel: concentrations; mean values and range of duplicates are given. If no range is indicated it is smaller than the symbols. Lower panel: TDAA $A_{\text {lab }}$ as percent of bulk TDAA and DOC lab. For comparison with DOC TDAA were translated into $C$ on the basis of the amount of $C$ per amino acid (ca $46 \mathrm{~g} \mathrm{C} \mathrm{mol}^{-1}$ amino acid) 


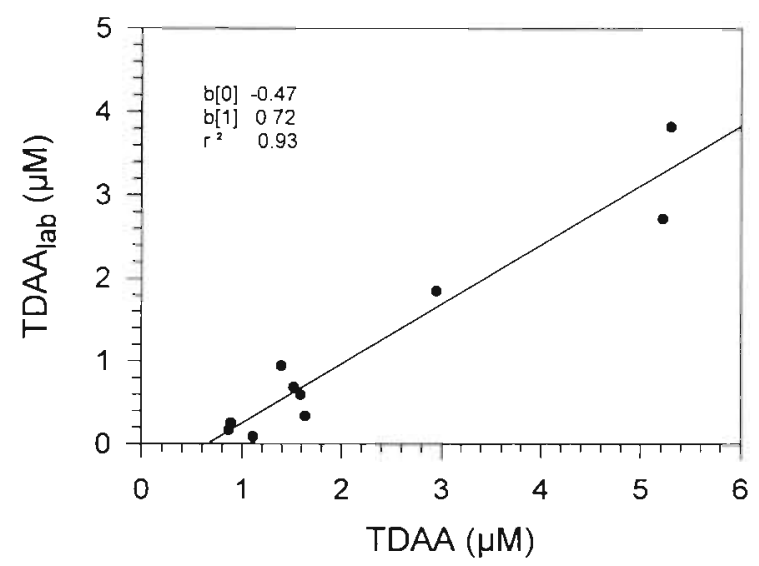

Fig. 5. Linear correlation $(p<0.01)$ of labile and bulk TDAA

TDCHO were not consumed in equal amounts, neither during the time course of the experiments nor seasonally (Fig. 3). Whereas on May 3 TDCHO were consumed during the initial phase of the incubation prior to the period of cell growth and excreted thereafter, TDAA were consumed during the time when bacteria were growing. On June 14 TDCHO were the dominant substrates for bacterial growth and TDAA made up only $20 \%$ of the substrates utilized (Table 2). Both substrates were excreted during the later growth phase as reflected also by an enhanced DOC concentration at $65 \mathrm{~h}$. TDAA were the dominant substrates on May 3 and on July 5, whereas in the other experiments TDCHO comprised $80 \%$ of the identified substrates utilized. Concentrations of labile TDCHO and bulk $\mathrm{TDCHO}$ exhibited a significant positive correlation $\left(\mathrm{r}^{2}=0.85, \mathrm{n}=4, \mathrm{p}<0.01\right)$.

\section{Bacterial turnover and respiration of DFAA and glucose}

The turnover of DFAA and glucose exhibited systematic differences and varied greatly. The turnover time of DFAA ranged from $<6$ h at 2 and $8 \mathrm{~m}$ in July and August to 100 to $250 \mathrm{~h}$ during the spring bloom and at 20 and $40 \mathrm{~m}$ (Fig. 6). It was faster than that of glucose by a factor of 5 to 10 except at 2 and $8 \mathrm{~m}$ from mid-July until September, when differences were less than 2 -fold. The turnover time of glucose exceeded $200 \mathrm{~h}$ from March until mid-July at 2 and $8 \mathrm{~m}$ except for a brief period during the spring bloom (Fig. 6). At 20 and $40 \mathrm{~m}$ it was always longer than $100 \mathrm{~h}$ with highest values exceeding even $1000 \mathrm{~h}$. The systematic differences between the turnover times of DFAA and glucose are also evident from their seasonal means (Table 3).

The relative proportions of glucose and DFAA respired exhibited large variations even though in general the proportions were in the same range (Fig. 7, Table 3). In April and May during the spring bloom proportions of DFAA respired were higher than those of glucose except in a few cases at 2 and $8 \mathrm{~m}$ at the end of April and in early May at its maximum. At the end of May at the highest rates of bacterial production proportions of glucose and DFAA respired were similar at 2 and $8 \mathrm{~m}$, whereas during the clear-water phase at $2 \mathrm{~m}$ a higher proportion of DFAA was respired than of glucose. From mid-June until the end of July at 2 and $8 \mathrm{~m}$, however, higher proportions of glucose were respired than of DFAA. From August until October both substrates were respired in equal proportions at these depths. In May and June large variations of the percentage of glucose respired occurred at $20 \mathrm{~m}$ without a clear tendency relative to that of DFAA. From late August until mid-September at $40 \mathrm{~m}$, a relatively higher proportion of DFAA as compared to glucose was respired. Due to the non-regular patterns of these inverse relationships over longer time periods they did not show up in statistical evaluations. During the spring bloom and in summer there was a general, even though not statistically significant, tendency of higher respiration percentages of amino acids with depth (Table 3). The same was true for glucose during the spring bloom, whereas in summer the opposite was true.

Table 2. Bacterial consumption and relative fractions of bulk and labile dissolved carbohydrates (TDCHO, TDCHO $\mathrm{Iab}_{\mathrm{b}}$ ), labile dissolved amino acids (TDAA $\hat{A}_{\text {lab }}$ ) aud labile DOC measured in i um filtered samples from Lake Constance. The initial concentrations of TDCHO in the experiments are also given $\left(\mathrm{TDCHO}_{\mathrm{m} t \mathrm{t}}\right)$. TDCHO $\mathrm{TDb}_{\mathrm{lab}}+\mathrm{TDAA}_{\mathrm{lab}}$ as $\% \mathrm{DOC}_{\text {lab }}$ were calculated on the basis of the hourly rates. Mean values of duplicates are given

\begin{tabular}{|c|c|c|c|c|c|c|c|c|}
\hline \multirow{2}{*}{$\begin{array}{l}\text { Date } \\
3 \text { May }\end{array}$} & \multicolumn{2}{|c|}{$\begin{array}{c}\mathrm{TDCHO}_{\mathrm{int}} \\
\left(\mu \mathrm{Cl}^{-1}\right) \quad(\mu \mathrm{M})\end{array}$} & \multicolumn{3}{|c|}{$\begin{array}{c}\mathrm{TDCHO}_{\text {lab }} \\
\left(\mu \mathrm{g} \mathrm{Cl}^{-1} \mathrm{~h}^{-1}\right)(\% \mathrm{TDCHO})\left(\% \mathrm{DOC}_{\text {lab }}\right)\end{array}$} & \multirow{2}{*}{$\begin{array}{c}\begin{array}{c}\mathrm{TDAA}_{\text {lab }} \\
\left(\mu \mathrm{g} \mathrm{\textrm {Cl } ^ { - 1 }} \mathrm{h}^{-1}\right)\end{array} \\
2.60\end{array}$} & \multirow{2}{*}{$\begin{array}{c}\begin{array}{c}\mathrm{DOC}_{\mathrm{lab}} \\
\left(\mu \mathrm{Cl}^{-1} \mathrm{~h}^{-1}\right)\end{array} \\
6.43\end{array}$} & \multirow{2}{*}{$\frac{\begin{array}{c}\mathrm{TDCHO}_{\text {lat }}+\mathrm{TDAA}_{\text {lab }} \\
\left(\% \mathrm{DOC}_{\text {lab }}\right)\end{array}}{55.5}$} \\
\hline & 92.9 & 1.34 & 0.97 & 23.9 & 4.9 & & & \\
\hline 14 Jun & 251.8 & 3.62 & 4.18 & 73.1 & 86.0 & 1.07 & 4.86 & 108.0 \\
\hline $5 \mathrm{Jul}$ & 161.1 & 2.34 & 0.78 & 36.6 & 20.9 & 1.01 & 3.73 & 48.0 \\
\hline $13 \mathrm{Sep}$ & 82.6 & 1.19 & 1.31 & 65.3 & 56.7 & 0.32 & 2.32 & 70.0 \\
\hline
\end{tabular}


Glucose

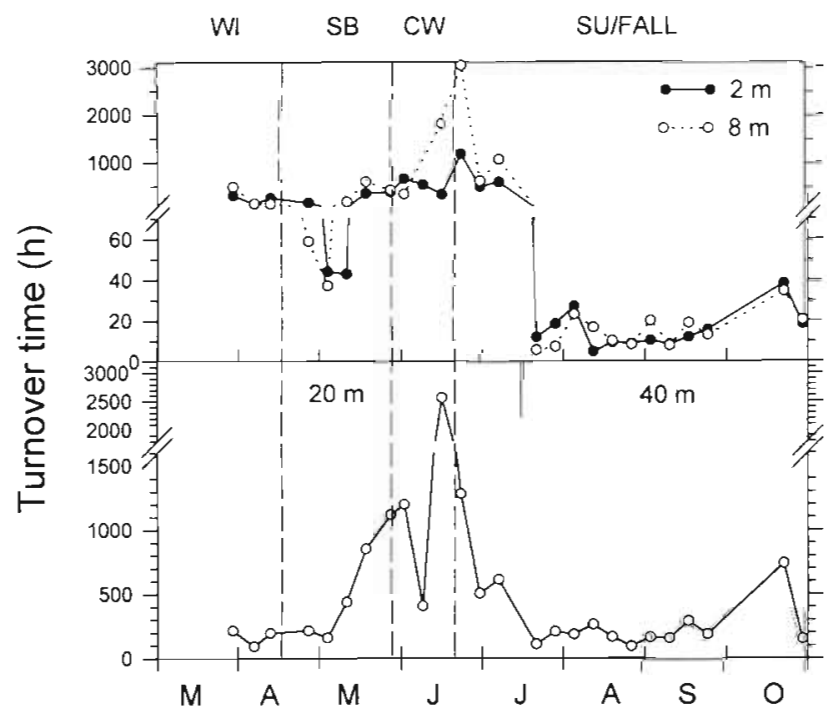

DFAA

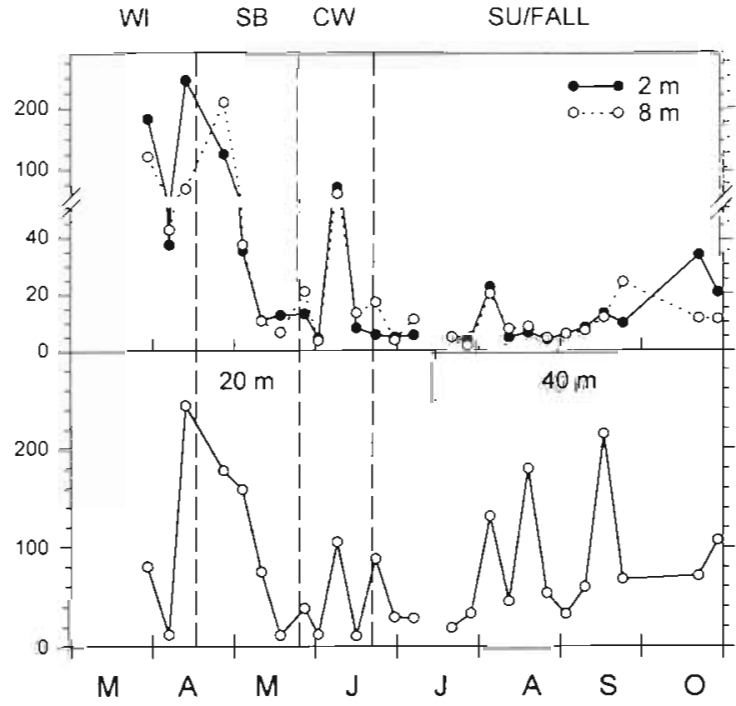

Fig. 6. Turnover times of glucose (left panel) and DFAA (right panel) at 2, 8 and 20 or $40 \mathrm{~m}$ depth in Lake Constance between late March and October 1994. Due to the scale break the lines between 2 data points of the turnover time of glucose at 2 and $8 \mathrm{~m}$ in July appear with different slopes. For abbreviations see Fig. 2

Table 3. Mean values of bacterial production (BP), bacterial cell numbers (BN), bacterial growth rates (growth), turnover times of glucose ( $\mathrm{T} \mathrm{glc}$ ) and DFAA (T dfaa), and percent respiration of glucose (Resp glc) and DFAA (Resp dfaa) at 2, 8 , and 20 or $40 \mathrm{~m}$ depth for the entire investigation period (total season), the spring bloom (Apr 16-May 31), the clear-water phase (Jun 1-20), and the summer-fall period (Jul 1-Oct 31)

\begin{tabular}{|c|c|c|c|c|}
\hline & Total season & Spring & Clear-water & Summer-fall \\
\hline \multicolumn{5}{|l|}{$2 \mathrm{~m}$} \\
\hline $\mathrm{BP}\left(\mu \mathrm{gCl} \mathrm{l}^{-1} \mathrm{~h}^{-1}\right)$ & $1.22 \pm 1.07$ & $1.55 \pm 1.42$ & $0.80 \pm 0.82$ & $1.40 \pm 0.84$ \\
\hline $\mathrm{BN}\left(10^{6} \mathrm{ml}^{-1}\right)$ & $4.55 \pm 2.45$ & $7.22 \pm 3.28$ & $3.95 \pm 2.03$ & $4.29 \pm 1.17$ \\
\hline Growth $\left(\mathrm{d}^{-1}\right)$ & $0.28 \pm 0.24$ & $0.24 \pm 0.20$ & $0.20 \pm 0.15$ & $0.37 \pm 0.25$ \\
\hline T glc $\left(\mathrm{h}^{-1}\right)$ & $360.0 \pm 679.0$ & $265.4 \pm 197.7$ & $1719.4 \pm 1101.0$ & $15.3 \pm 8.1$ \\
\hline $\mathrm{T} \operatorname{dfaa}\left(\mathrm{h}^{-1}\right)$ & $34.2 \pm 58.5$ & $33.1 \pm 41.6$ & $21.6 \pm 27.4$ & $10.9 \pm 8.7$ \\
\hline Resp glc $(\%)$ & $27.5 \pm 11.4$ & $25.9 \pm 13.7$ & $20.3 \pm 25.5$ & $30.3 \pm 7.4$ \\
\hline Resp dfaa (\%) & $27.0 \pm 9.0$ & $28.0 \pm 12.2$ & $24.2 \pm 6.4$ & $27.6 \pm 8.9$ \\
\hline \multicolumn{5}{|l|}{$8 \mathrm{~m}$} \\
\hline 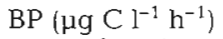 & $0.93 \pm 0.85$ & $1.03 \pm 1.11$ & $0.27 \pm 0.24$ & $1.25 \pm 0.71$ \\
\hline $\mathrm{BN}\left(10^{6} \mathrm{ml}^{-1}\right)$ & $3.97 \pm 1.99$ & $5.30 \pm 3.15$ & $2.68 \pm 0.57$ & $4.34 \pm 1.21$ \\
\hline Growth $\left(\mathrm{d}^{-1}\right)$ & $0.25 \pm 0.18$ & $0.23 \pm 0.20$ & $0.11 \pm 0.08$ & $0.32 \pm 0.15$ \\
\hline $\mathrm{Tglc}\left(\mathrm{h}^{-1}\right)$ & $212.5 \pm 277.9$ & $266.9 \pm 215.4$ & $666.6 \pm 314.4$ & $15.1 \pm 9.0$ \\
\hline$T$ dfaa $\left(h^{-1}\right)$ & $28.2 \pm 44.1$ & $47.6 \pm 72.7$ & $22.9 \pm 21.0$ & $9.9 \pm 5.9$ \\
\hline Resp glc $(\%)$ & $28.9 \pm 11.9$ & $23.4 \pm 13.4$ & $51.5 \pm 22.3$ & $29.4 \pm 6.5$ \\
\hline Resp dfaa (\%) & $29.1 \pm 10.9$ & $29.3 \pm 14.8$ & $29.5 \pm 11.3$ & $27.4 \pm 8.7$ \\
\hline \multicolumn{5}{|l|}{20 or $40 \mathrm{~m}$} \\
\hline $\mathrm{BP}\left(\mu \mathrm{gCl^{-1 }} \mathrm{h}^{-1}\right)$ & $0.23 \pm 0.26$ & $0.36 \pm 0.46$ & $0.18 \pm 0.11$ & $0.21 \pm 0.18$ \\
\hline $\mathrm{BN}\left(10^{6} \mathrm{ml}^{-1}\right)$ & $1.63 \pm 0.91$ & $2.35 \pm 1.03$ & $2.40 \pm 0.83$ & $1.01 \pm 0.38$ \\
\hline Growth $\left(\mathrm{d}^{-1}\right)$ & $0.18 \pm 0.19$ & $0.17 \pm 0.15$ & $0.09 \pm 0.02$ & $0.24 \pm 0.23$ \\
\hline T glc $\left(\mathrm{h}^{-1}\right)$ & $481.0 \pm 541.1$ & $661.9 \pm 414.8$ & $1358.8 \pm 770.9$ & $223.7 \pm 164.6$ \\
\hline $\mathrm{T}$ dfaa $\left(\mathrm{h}^{-1}\right)$ & $79.9 \pm 65.4$ & $78.5 \pm 66.8$ & $53.5 \pm 43.3$ & $80.0 \pm 58.7$ \\
\hline Resp glc $(\%)$ & $23.2 \pm 16.8$ & $33.7 \pm 26.7$ & $17.6 \pm 25.2$ & $21.0 \pm 9.3$ \\
\hline Resp dfaa $(\%)$ & $34.1 \pm 13.6$ & $35.2 \pm 12.6$ & $28.5 \pm 4.1$ & $35.8 \pm 16.4$ \\
\hline
\end{tabular}




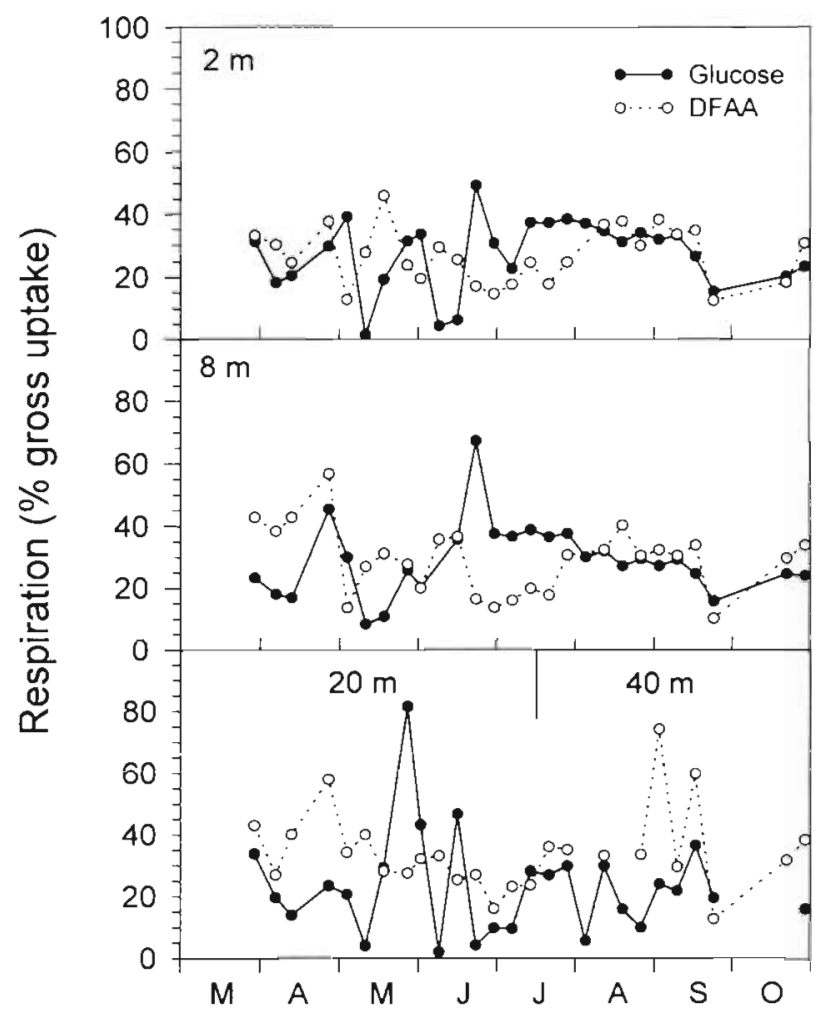

Fig. 7. Respiration as \% of gross uptake of glucose and DFAA at 2,8 and 20 or $40 \mathrm{~m}$ depth in Lake Constance between late March and October 1994. Gross uptake is net uptake + respiration

\section{DISCUSSION}

It is a well-known fact supported by a large number of studies that the DOC pool in pelagic ecosystems is constituted of a recalcitrant and a labile fraction which can comprise between $<5$ and ca $40 \%$ of total DOC (for review see Søndergaard \& Middelboe 1995). This review showed that the concentration of labile DOC is positively related to that of total DOC across systems although differently in limnetic, riverine, and marine systems. But also within systems, variations of the absolute concentrations and relative fractions of labile DOC occur even though this is documented only by a few studies. In Danish eutrophic lakes, the absolute concentration of labile DOC was shown to vary from ca 600 to $1400 \mu \mathrm{g} \mathrm{C}^{-1}$, comprising $<10 \%$ of total DOC (Middelboe \& Søndergaard 1993, Søndergaard et al. 1995). So it appears remarkable that we found a seasonal variation of the concentration of labile DOC by a factor of 8 and its relative proportion of total DOC varying from 5 to $36 \%$, roughly the total range found in other limnetic systems. The seasonal mean of $13 \%$ of our values complies with that of $14 \%$ determined by Søndergaard \& Middelboe (1995) for all lakes included in their analysis.
The fact that we incubated the $1 \mu \mathrm{m}$ filtered samples at in situ temperatures may have biased the results at low temperatures, i.e. reduced the consumption of DOC by bacteria because they may have been temperature limited and thus not consumed the labile DOC completely during the incubation time. Simon \& Wünsch (1998), however, showed that epilimnetic planktonic bacteria in Lake Constance are well temperature-adapted during the growing season. Therefore, we can exclude a large temperature effect on our results.

Our results showed that labile TDAA were important components of the pools of labile DOC and bulk TDAA. The close and highly significant positive correlation between the concentrations of bulk TDAA and ils labile component indicated that with increasing concentrations of TDAA its labile fraction increased relatively. Hence, the dynamics of bulk TDAA seem to be predominantly controlled by that of labile TDAA. As indicated by the intercept with the $x$-axis at $0.72 \mu \mathrm{M}$ TDAA (Fig. 5), at this concentration no labile components are available. In fact, concentrations around this value occur in Lake Constance from September to November in the epilimnion and particularly in the hypolimnion (Simon 1998), suggesting that only a minor fraction of TDAA, if any, is labile in these situations. At the spring bloom and in late July labile TDAA constituted $>60 \%$ of the labile DOC, whereas at other times $<25 \%$ of the latter were TDAA. These observations, substantiated by the fact that no significant correlation between these parameters existed, indicate that labile TDAA did not generally control the pool of labile DOC.

Labile TDCHO were also an important component of the pools of labile DOC and bulk TDCHO. At times of relatively low rates of bacterial production such as in June during the clear-water phase and in September, they comprised large proportions of both bulk TDCHO and dominated the labile DOC (Table 2). During the spring bloom and in July at high rates of bacterial production they comprised not more than $21 \%$ of labile DOC and labile TDAA were dominating. This observation indicates that TDCHO and TDAA are utilized by planktonic bacteria to varying degrees depending on the supply and availability of these substrates and yielding different growth responses (see below). The positive correlation between labile and bulk TDCHO suggested that, as for TDAA, concentrations of bulk TDCHO were largely controlled by that of labile TDCHO and that with increasing concentration of TDCHO its labile fraction relatively increased. However, since this correlation is based only on 4 data points we consider it as a preliminary result.

In 2 of the 4 experiments which simultaneously measured bacterial consumption of labile TDAA and 
TDCHO these compounds constituted 70 and $100 \%$ of the labile DOC whereas in the other 2 they constituted roughly $50 \%$ of it. This mass balance confirms that amino acids and carbohydrates are important and often the dominant components of the labile DOC pool. It also indicates, however, that there is a gap at certain times, leaving room for other components or indicating that our analyses missed some of the TDAA and TDCHO. A similar gap in mass balance was reported by Jørgensen et al. (1998) from experiments in a Swedish lake examining bacterial utilization of DOC, TDAA and TDCHO and applying the same analytical procedures as we did. Using a more rigorous vaporphase hydrolysis procedure of TDAA Keil \& Kirchman (1993) yielded higher concentrations of TDAA than using the classic liquid-phase hydrolysis procedure at $110^{\circ} \mathrm{C}$ for $24 \mathrm{~h}$ we applied. However, these authors showed that this additional fraction of TDAA was much more recalcitrant than the one hydrolyzed by the classic procedure. Therefore, we assume that we did not miss a significant fraction of labile TDAA. With respect to hydrolysis of TDCHO we also applied a procedure using $\mathrm{HCl}$ and not sulfuric acid as suggested by Pakulski \& Benner (1992) which gives higher yields of TDCHO. In contrast to TDAA, this more rigorous procedure to a certain extent yields a readily available fraction as shown by Hanisch et al. (1996), who found that bacteria can sometimes consume only the sulfuric acid-hydrolyzable fraction and not the $\mathrm{HCl}$ hydrolyzable one. Even though we are aware of this drawback we used the $\mathrm{HCl}$ hydrolysis procedure due to problems in neutralizing the acidic hydrolysate after sulfuric acid treatment for our HPLC analysis. Further, Mopper et al. (1995) found that the analysis of hydrolyzed polysaccharides by HPLC yields lower concentrations than the analysis by the MBTH method (Johnson \& Sieburth 1977), presumably because in addition to neutral hexoses also acidic hexoses and pentoses are detected with the same sensitivity. Hence, we may have missed an unknown fraction of the labile TDCHO due to incomplete hydrolysis and the fact that we only detected neutral monosaccharides by our HPLC analysis. Because in one experiment we could account for $100 \%$ of the labile DOC by labile TDAA and TDCHO and in another experiment for $70 \%$ we assume, however, that we detected the majority of labile TDCHO in these cases. We can only speculate whether other dissolved organic compounds may also have contributed to the labile DOM pool. Other organic compounds such as dissolved DNA or fatty acids seem not to be important components of the labile DOC pool (Jørgensen et al. 1993, Münster 1993).

An interesting finding was that TDAA appeared to be preferred when high concentrations were available and when bacterioplankton production was high, whereas TDCHO were preferentially consumed at low concentrations of labile TDAA such as during the clear-water phase in June. Hanisch et al. (1996) also found the highest rates of consumption of TDCHO during the clear-water phase. These results agree with findings of Kirchman (1990) who reported that heterotrophic bacteria preferred DFAA against glucose. Also Tranvik \& Jørgensen (1995) in mesocosm experiments in 2 Swedish lakes found that amino acids were the preferred substrates for bacterioplankton growth as compared to glucose. On the other hand, Jørgensen et al. (1998) found that in epilimnetic waters of a clear water lake in July TDCHO were the preferred substrates as compared to TDAA whereas in hypolimnetic waters TDAA were favored and TDCHO even excreted. We want to note that in our experiments during the incubation of the $1 \mu \mathrm{m}$ filtrates both substrate classes were also used differently over time and that TDCHO sometimes were excreted as well. These approaches, however, did not determine whether amino acids or carbohydrates were preferentially used for biosynthetic or energy requirements because they only measured total bacterial consumption, i.e. decrease in concentration over time.

Our results on respiration of amino acids and glucose gave further indications that both substrate classes often were used differently for energy and biosynthetic requirements. During the spring bloom when utilization of TDAA explained a large fraction of the bacterial carbon demand (Table 2) DFAA were respired to a higher proportion than glucose. In contrast, in July, when utilization of amino acids also explained a large fraction of the bacterial carbon demand (Rosenstock \& Simon 1993) glucose was respired to a higher proportion than DFAA. Other factors such as the C:N ratio of amino acids relative to that of the bacterial biomass (Goldman et al. 1987, Jørgensen et al. 1994), the availability of a nitrogen source, e.g. ammonium (Kirchman et al. 1990), and the simultaneous availability of TDCHO (Gardner et al. 1996), and the physiological and/or phenotypical adaptation of the ambient bacterial community to the substrates available may affect the metabolic fate of amino acids and carbohydrates as well. In fact, Schweitzer \& Simon (1995) showed that planktonic bacteria in Lake Constance in May during the spring bloom exhibited a higher growth efficiency when utilizing glucose and ammonium as compared to amino acids whereas in June the opposite was true.

We want to point out that the absolute proportions of DFAA and glucose respired we found may have been biased if isotopic equilibrium of the label taken up into the bacterial biomass and thus of the ${ }^{14} \mathrm{CO}_{2}$ produced was not reached during the time of incubation. Berman \& Gerber (1980) and Itturiaga \& Zsolnay (1981) emphasize that this phenomenon may lead to underestimated 
rates of uptake and respiration of radioisotopes. The unrealistically low respiration percentages we sometimes measured may have been affected by this problem even though we can not rule out that other unnoticed experimental errors such as incomplete acidification or trapping of the ${ }^{14} \mathrm{CO}_{2}$ produced occurred as well.

The overall bacterial respiration of substrates used for growth (1 - growth efficiency) was substantially lower than the proportions of DFAA and glucose respired and ranged between 43 and $92 \%$. This is a further indication that the respired proportions of these 2 major substrate classes were higher than determined by the radiotracer approach or that the respiration of DCAA and DDCHO was higher than that of the respective monomers. The bacterial growth efficiencies ranged between 8 and $57 \%$ and thus were in the range found in various other studies (Tranvik 1988, Kristiansen et al. 1992, Middelboe et al. 1992, Kroer 1993, Middelboe \& Søndergaard 1993, Søndergaard \& Theil-Nielsen 1997). Even though we found differences in the growth efficiencies at different seasons and substrate supply there was no clear relationship between substrate availability, e.g. concentrations of labile TDAA or TDCHO or bacterial growth rates, and the growth efficiency. Positive relationships have been reported between the growth efficiency and substrate lability (Middelboe \& Søndergaard 1993) and between the former and bacterial growth rates (Middelboe et al. 1992, Søndergaard \& Theil-Nielsen 1997).

The different dynamics and utilization of amino acids and carbohydrates by the planktonic bacteria became also evident from the different turnover times of DFAA and glucose. The turnover time of the glucose pool was always much greater than that of DFAA except at 2 and $8 \mathrm{~m}$ from the end of July until October when both pools were turned over at roughly equal rates. Greater turnover times of glucose relative to amino acids were also reported by Berman \& Gerber (1980) from Lake Kinneret, Israel, even though differences were not as pronounced as in Lake Constance. Because concentrations of both DFAA and dissolved free monosaccharides (DFCHO) including glucose are roughly similar in Lake Constance (Simon 1998, Simon et al. 1998), these differences suggest that either release and uptake rates of DFAA are much faster than those of DFCHO or that bacterial utilization of the 2 polymeric pools, from which most of the monomers originate, is different during certain periods and depths. We have no indication that DFCHO are less readily taken up by bacteria than DFAA. However, it is conceivable that at certain seasonal situations coupling between hydrolysis of the polymers and uptake of the monomers differs between the 2 substrate classes or that a large fraction of DCCHO is utilized directly as oligomers (Muir et al. 1985), leaving the DFCHO pool aside whereas uptake of DCAA is channeled mainly through the uptake of DFAA.

In conclusion we have shown that TDAA and TDCHO are major substrates for bacterioplankton growth in Lake Constance and constitute to a great extent the labile DOC pool. Both substrate classes, however, often are utilized differently for biosynthetic and energy requirements and at different seasonal situations depending on their availability and presumably on the physiological and genotypical adaptation of the bacterioplankton community. Therefore, the dynamics of both substrate classes often are different as reflected by the turnover times of DFAA and glucose.

Acknowledgements. We would like to thank our colleagues on board our RV 'Robert Lauterborn' for help in the field, H.H. Stabel at the Lake Constance Water Supply at Sipplingen (BWV) for the DOC analyses and C. Bunte for the TDCHO analyses. We also appreciate valuable comments by $M$. Søndergaard and $\mathrm{B}$. Rosenstock on an earlier draft of the manuscript. This work was part of the Special Collaborative Program 'Cycling of Matter in Lake Constance' funded by the Deutsche Forschungsgemeinschaft.

\section{LITERATURE CITED}

Amon RMW, Benner R (1996) Bacterial utilization of different size classes of dissolved organic matter. Limnol Oceanogr 41:41-51

Baines SB, Pace ML (1991) The production of dissolved organic matter by phytoplankton and its importance to bacteria: patterns across marine and freshwater systems Limnol Oceanogr 36:1078-1090

Berman T, Gerber C (1980) Differential filtration studies of carbon flux from living algae to microheterotrophs, microplankton size distribution and respiration in Lake Kinneret. Microb Ecol 6:189-198

Coffin RB (1989) Bacterial upake of dissolved free and combined amino acids in estuarine waters. Limnol Oceanogr $34: 531-542$

Gaedke U, Straile D (1994) Seasonal changes of the quantitative importance of protozoans in a large lake. An ecosystem approach using mass-balanced carbon flow diagrams. Mar Microb Food Webs 8:163-188

Gardner WS, Benner R, Amon RMW, Cotner JB, Cavaletto JT, Inhnson IR (1996) Efferts of high molecular-weight dissolved organic matter on nitrogen dynamics in the Mississippi River plume. Mar Ecol Prog Ser 133:287-297

Goldman JC, Caron DA, Dennett MR (1987) Regulation of gross growth efficiency and ammonium regeneration in bacteria by substrate $\mathrm{C}: \mathrm{N}$ ratio. Limnol Oceanogr 32 $1239-1253$

Güde H, Rossknecht H, Wagner G (1998) Anthropogenic impacts on the trophic state of Lake Constance during the 20th century. Arch Hydrobiol Spec Issues Adv Limnol 53:85-108

Hanisch K, Schweitzer B, Simon M (1996) Use of dissolved carbohydrates by planktonic bacteria in a mesotrophic lake. Microb Ecol 31:41-55 
Hedges JI (1992) Global biogeochemical cycles: progress and problems. Mar Chem 39:67-93

Hobbie JE, Crawford CC (1969) Respiration corrections for bacterial uptake of dissolved organic compounds in natural waters. Limnol Oceanogr 14:528-532

Itturiaga R, Zsolnay A (1981) Transformation of some dissolved organic compounds by natural heterotrophic populations. Mar Biol 62:125-129

Johnson KM, Sieburth JMcN (1977) Dissolved carbohydrates in seawater. I. A precise spectrophotometric analysis for monosaccharides. Mar Chem 5:1-13

Jørgensen NOG (1987) Free amino acids in lakes: concentrations and assimilation rates in relation to phytoplankton and bacterial production. Limnol Oceanogr 32:97-111

Jørgensen NOG (1990) Assimilation of free monosaccharides and amino acids relative to bacterial production in eutrophic lake water. Arch Hydrobiol Beih Ergebn Limnol 34:99-110

Jørgensen NOG, Jensen RE (1994) Microbial fluxes of free monosaccharides and total carbohydrates in freshwater determined by PAD-HPLC. FEMS Microbiol Ecol 14:79-94

Jørgensen NOG, Kroer N, Coffin RB, Yuang XH, Lee C (1993) Dissolved free amino acids, combined amino acids, and DNA as sources of carbon and nitrogen to marine bacteria. Mar Ecol Prog Ser 98:135-148

Jørgensen NOG, Kroer N, Coffin RB (1994) Utilization of dissolved nitrogen by heterotrophic bacterioplankton: effects of substrate $\mathrm{C} / \mathrm{N}$ ratio. Appl Environ Microbiol 60 . $4124-4133$

Jørgensen NOG, Tranvik L, Edling H, Graneli W, Lindell M (1998) Effects of sunlight on occurrence and bacterial turnover of specific carbon and nitrogen compounds in lake water. FEMS Microbiol Ecol 25:217-227

Keil RG, Kirchman DL (1993) Dissolved combined amino acids: chemical forms and utilization by marine bacteria. Limnol Oceanogr 38:1256-1270

Kirchman DL (1990) Limitation of bacterial growth by dissolved organic matter in the subarctic Pacific. Mar Ecol Prog Ser 62:47-54

Kirchman DL, K'nees E, Hodson RE (1985) Leucine incorporation and its potential as a measure of protein synthesis by bacteria in natural systems Appl Environ Microbiol 49 . 599-607

Kirchman DL, Keil RG, Wheeler PA (1990) Carbon limitation of ammonium uptake by heterotrophic bacteria in the subarctic Pacific. Limnol Oceanogr 35:1258-1266

Kirchman DL, Suzuki Y, Garside C, Ducklow HW (1991) High turnover rates of dissolved organic carbon during a spring phytoplankton bloom. Nature 352:612-614

Kristiansen, K, Nielsen H, Riemann B, Fuhrman JA (1992) Growth efficiencies of freshwater bacterioplankton. Microb Ecol 24:145-160

Kroer N (1993) Bacterial growth efficiency on natural dissolved organic matter. Limnol Oceanogr 38:1282-1290

Lampert W (1978) Release of dissolved organic carbon by grazing zooplankton. Limnol Oceanogr 23:831-834

Lindroth P, Mopper K (1979) High performance liquid chromatographic determinations of subpicomole amounts of amino acids by precolumn fluorescence derivatization with o-phthaldialdehyde. Anal Chem 51:1667-1674

Middelboe M. Sondergaard M (1993) Bacterioplankton growth yield: seasonal variation and coupling to substrate lability and $\beta$-glucosidase activity. Appl Environ Microbiol 59:3916-3921

Middelboe M, Nielsen B, Søndergaard M (1992) Bacterial utilization of dissolved organic carbon (DOC) in coastal waters. Determination of growth yield. Arch Hydrobiol
Beih Ergebn Limnol 37:51-61

Middelboe M, Borch NH, Kirchman DL (1995) Bacterial utilization of dissolved free amino acids, dissolved combined amino acids and ammonium in the Delaware Bay estuary: effects of carbon and nitrogen limitation. Mar Ecol Prog Ser 128:109-120

Mopper K, Schultz CA, Chevolot L, Germain C, Revuelta R Dawson R (1992) Determinations of sugars in unconcentrated seawater and other natural waters by liquid chromatography and pulsed amperometric detection. Environ Sci Technol 26:133-138

Mopper K, Zhou J, Ramana KS, Passow U, Dam H, Drapeau D (1995) The role of surface-active carbohydrates in the flocculation of a diatom bloom in a mesocosm. Deep-Sea Res $42: 47-73$

Muir M, Williams L, Ferenci T (1985) Influence of transport energization on the growth of Escherichia coli. J Bacteriol 163:1237-1242

Münster U (1993) Concentrations and fluxes of organic carbon substrates in the aquatic environment. Antonie Leeuwenhoek 63:243-274

Pakulski JD, Benner R (1992) An improved method for the hydrolysis and MBTH analysis of dissolved and particulate carbohydrates in seawater. Mar Chem 40:143-160

Porter KG, Feig YS (1980) The use of DAPI for identifying and counting aquatic microflora. Limnol Oceanogr 25 : 943-948

Rich J, Ducklow HW, Kirchman DL (1996) Concentrations and uptake of neutral monosaccharides along $140^{\circ} \mathrm{W}$ in the equatorial Pacific: contribution of glucose to heterotrophic bacterial activity and the DOM-flux. Limnol Oceanogr 41 : 595-604

Riemann B, Sondergaard M, Schierup HH, Bosselmann S, Christensen G, Hansen J, Nielsen B (1982) Carbon metabolism during a spring diatom bloom in the eutrophic lake Mossa. Int Revue Ges Hydrobiol 67:145-185

Rosenstock B, Simon M (1993) Utilization of dissolved combined and free amino acids by planktonic bacteria in Lake Constance. Limnol Oceanogr 38:1521-1531

Schweitzer B. Simon M (1995) Limiting nutrients for bacterioplankton growth in a mesotrophic temperate large lake. Microb Ecol 30:89-104

Simon M (1998) Bacterioplankton dynamics in a large mesotrophic lake: II concentrations and turnover of dissolved amino acids. Arch Hydrobiol 144:1-23

Simon M, Azam F (1989) Protein content and protein synthesis rates of planktonic marine bacteria. Mar Ecol Prog Ser 51:201-213

Simon M, Rosenstock B (1992) Carbon and nitrogen sources of planktonic bacteria in Lake Constance studied by the composition and isotope dilution of intracellular amino acids. Limnol Oceanogr 37:1496-1511

Simon M, Tilzer MM (1987) Bacterial response to seasonal changes in primary production and phytoplankton biomass in Lake Constance. J Plankton Res 9:535-553

Simon M, Wünsch C (1998) Temperature control of bacterioplankton growth in a temperate large and deep mesotrophic lake. Aquat Microb Ecol 16:119-130

Simon M, Bunte C, Schulz M, Weiss M, Wünsch C (1998) Bacterioplankton dynamics in Lake Constance (Bodensee): substrate utilization, growth control, and long-term trends. Arch Hydrobiol Spec Issues Adv Limnol 53: $195-221$

Sondergaard M, Middelboe M (1995) A cross-system analysis of labile organic carbon. Mar Ecol Prog Ser 118: $283-294$

Sondergaard M, Theil-Nielsen J (1997) Bacterial growth effi- 
ciency in lakewater cultures. Aquat Microb Ecol 12: $115-122$

Sondergaard M, Hansen B, Markager S (1995) Dynamics of dissolved organic carbon lability in a eutrophic lake. Limnol Oceanogr 40:46-54

Strom SL, Benner R, Ziegler S, Dagg M (1997) Planktonic grazers are a potentially important source of marine dissolved organic matter. Limnol Oceanogr 42:1364-1374

Suttle CA, Chan AM, Fuhrman JA (1991) Dissolved free amino acids in the Sargasso Sea: uptake and respiration rates, turnover times, and concentrations Mar Ecol Prog Ser 70:189-199

Tranvik LJ (1988) Availability of dissolved organic carbon for planktonic bacteria in oligotrophic lakes of differing

Editorial responsibility: Karel Simek,

Ceské Budĕjovice, Czech Republic humic content. Microb Ecol 16:311-322

Tranvik IJ (1990) Bacterioplankton growth on fractions of dissolved organic carbon of different molecular weights from humic and clear waters. Appl Environ Microbiol 56:1672-1677

Tranvik LJ, Jørgensen NOG (1995) Colloidal and dissolved organic matter in lake water: carbohydrate and amino acid composition, and ability to support bacterial growth. Biogeochemistry 30:77-97

Volk CJ, Volk CB, Kaplan LA (1997) Chemical composition of biogedradable dissolved organic matter in streamwater. Limnol Oceanogr 42:39-44

Weisse T, Müller H (1998) Planktonic protozoa and the microbial food web in Lake Constance. Arch Hydrobiol Spec Issues Adv Limnol 53:13-30

Submitted: July 24, 1998; Accepted: October 2, 1998 Proofs received from author(s): April 21, 1999 